\title{
Current Situation of Homoparental Adoption in Latin America: A Bioethical Problem of Discrimination, Rights and Social Justice
}

\section{Trevizo AV*}

Faculty of Medicine, National Autonomous University of México, Mexico

*Corresponding author: Ana Violeta Trevizo, Faculty of Medicine, Master's and Doctorate Program in Medical, Dental and Health Sciences of the National Autonomous University of Mexico, Email: violeta.trevizo@gmail.com

\section{Review Article}

Volume 4 Issue 1

Received Date: January 26, 2021

Published Date: February 12, 2021

DOI: $10.23880 /$ abca-16000158

\section{Abstract}

This article raises the current situation of homoparental adoption in Latin America. The problem of discrimination-exclusion and social justice. This work exposes the need to integrate the secular bioethical perspective in the public discussion and the contrast of conservative and liberal arguments on homoparental adoption. Likewise, the article exposes the urgent need to legislate in favor of children and not against same-sex couples or gay individuals who are trying to adopt. We recommend the promotion of bioethical education and social awareness to prevent violence and discrimination against vulnerable minorities through the teaching and practice of tolerance, respect, dialogue, and the bioethical principles of non-maleficence, dignity, integrity, and vulnerability.

Keywords: Bioethics; Homoparental Adoption; Latin America; Discrimination; Social Justice; Human Rights

\section{Methodology}

This work analyses the liberal and conservative stances through a bibliographic revision as the theoretical frame. It contrasts the content of both stances on same-sex marriage and homoparental adoption. The conservative position was examined by the discourse of Leon Kass, and the Catholic Church due to the predominance of this religion in LatinAmerican countries, particularly in Mexico contrasted with the liberal position of John Harris. Both are experts in bioethics and are internationally recognized in this field. It was systematically reviewed the laws and public policies available in Latin American countries about samesex marriage and homoparental adoption. This article proposes the inclusion of non-maleficence, integrity, dignity, vulnerability, fundamental rights, and social justice in the public discussion.

\section{Introduction}

Currently, child adoption besides being a manner to conform a family for heterosexual couples going through fertility problems, addresses the difficulty of reproduction in same-sex couples who don't want to go through the processes of assisted reproduction i.e. in vitro fertilization, artificial insemination or woman surrogacy. These procedures can be very distressing and expensive, mostly to people of Latin America due to the underdeveloped economy. Though, there is a significant bioethical problem; adoption is limited in most legal systems in Latin America to heterosexual couples, although homoparental adoption happens clandestinely due to the legal complexity of the procedure or its prohibition. Fortunately, many couples have children from previous relationships, being homosexual doesn't mean to be deprived of having children. National and international homoparental adoption can be a social mechanism -albeit to a lesser extent, to address the problem of overpopulation, poverty, migration in the wake of war, diseases such as AIDS that leave many children without family in developing countries. UNICEF in 2014 , recorded an estimated of 140,000 orphaned children around the world for various causes [1].

Uruguay, Mexico, Argentina, Brazil and Colombia are the only countries in Latin America that have allowed 
homoparental adoption trough different legal procedures. We must remember that homoparental adoption is a subject that has been in the discussion in Latin America just for the last decade. Marrying and having a family is a human right, regardless of whether the children are genetic or adoptive as stated in the Universal Declaration of Human Rights: "All women and men, from the age of marriage, are entitled, without restriction on grounds of race, nationality or religion, to marry and found a family, and to enjoy equal rights in marriage, during marriage and in case of dissolution of marriage" [2].

In 2009, Uruguay adopted a pioneering law that equated the rights of gay couples with those of heterosexual couples in relation to adoption. Before this law, homosexual persons in that country could only adopt as individuals but not as a couple. Senator Margarita Percovich, the promoter of the bill, said in the parliament that the issue is raised from the interest of children, not from adults. The adoption will therefore depend on the characteristics of the couple -whether homosexual or heterosexual, and what is aimed at is to analyze if it is good for the children, because that is their best interest. Clearly, Uruguayan society has cultural resistance to adoption by homosexual couples, and has tried to undermine the real purpose of the bill, which is to find the right couple or family environment for each child $[3,4]$.

In Mexico in 2010, after the legalization of samesex marriage in Mexico City, the debate on homoparental adoption inclined to the prohibition due to the influence of the conservative stance and the Catholic Church [5]. Despite this, homoparental adoption was attained only in Mexico City on November 17 of 2010. The Federal District Court of Justice ruled favorably, after a long process, the request for adoption of a child by a marriage of homosexual women. Subsequently, the Supreme Court of Justice, established that cohabitation societies, between same-sex couples or heterosexuals, conforms a family model recognized by the Constitution and therefore have the right to adopt, as well as to share or entrust the parental authority, guard and custody of the minor children of the other cohabiting partner. Some members of the Supreme Court affirmed that the issue goes beyond violating the rights of gay couples, saying that it is a general discriminatory act. This thesis was based on the Unconstitutionality Action 2/2010 on the best interest of the child in adoption by same-sex married couples [6].

Argentina, by approving the civil union between persons of the same sex on July 15,2010, in the law 26,618, gave these couples the right to adopt jointly [7], with the same requirements that already existed for marriages between persons of different sex established in the adoption law 24,779 [8]. The adoption institute is based on articles 311-340 of the Argentinian Civil Code. The debate on homoparental adoption in Argentina focuses on the fundamental right to equality and a more democratic society, appealing to equal marriage and the superior good of the child. Nevertheless, there was also opposition from the conservative stance, particularly by the Catholic Church, which organized demonstrations against homoparental adoption, convening more than 100,000 people in Buenos Aires [9].

In 2011, Brazil approved the stable union of samesex couples through the High Court of Justice due to the direct action of unconstitutionality 4277 and the charge of violation of the fundamental precept 132 . These lawsuits were filed in Court by the Attorney General and the Governor of Rio de Janeiro, Sergio Cabral, asking the exclusion of any sense of the article 1723 of the Civil Code which prevents the recognition of unions between same-sex couples as a family entity. The Court was asked that the same rights and obligations of couples in stable unions were extended to members of marriages between persons of the same sex. In the accusation of the violation of the fundamental precept 132, the state government of Rio de Janeiro said that nonrecognition of gay marriage goes against the fundamental principles of equality, freedom (which is derived from freedom of choice) and the principle of human dignity, all contemplated in the Constitution of that country [10].

The Constitutional Court in Colombia, in 2015 established the verdict C-683/15 in which it was determined that samesex couples are empowered to adopt jointly, according to the legal norms accused in law 1098 in the articles 64, 66 and 68 and in the law 54 in article one in accordance with the political constitution and international treaties on human rights, which consecrate the protection of the best interest of children and adolescents [11].

The prohibition of homoparental adoption in the rest of Latin America is related to the conservative stance, principally headed by the Catholic Church, which opposes; first because it is against marriage between same sex couples, since it affirms that it is not a "natural" process and that this union is penalized in its canons; secondly, it argues that homoparental adoption is against the well-being of the child to be adopted. It asserts that homosexual couples are incapable of raising a child, and that the natural or adoptive children of these couples can have serious psychological consequences because of the example and the possibility of becoming homosexual as well. They consider that the genetic or adoptive children of gay couples will suffer from social stigmatization [12]. However, this argument lacks of empirical evidence on this claim. Nowadays, democratic societies are in favor of the inclusion and the depathologization of homosexuality and against of any violation of human rights. 
The conservative stance based on the perspective of Leon Kass about same-sex marriage is that ideology may be pervasive in the social sciences especially when controversial policy issues are at stake like in same-sex marriage. He affirms that ideology is not science and that some decisions in policy have been made by political reasons and not on scientific evidence, like taking homosexuality off the Diagnostic and Statistical Manual of Mental Disorders (DSM) of the American Psychiatric Association back in 1970. Kass assures that there could conceivably come a time when supporters of traditional marriage are compelled by scientific evidence to acknowledge that same-sex marriage is not harmful to children or to society at large. But that day is not here, and there is not the slightest reason to think it is imminent. He asserts that is not less possible that scientific evidence will eventually show that redefining marriage to encompass unions of same-sex couples does have harmful effects on our society and its children. That day is also not yet here, nevertheless, he says there are no bases to conclude that it will never arrive [13].

In contrast, John Harris, on the liberal stance, states that if reproduction is allowed to people who are not qualified to have children as adolescents, people with addictions or with mental illness, people in prison, or even immature people (although they do not have the previous circumstances, that is to say people who are not prepared to have children), only because they live in heterosexual marriage, nothing guarantees that those children will not have some type of psychological problem when growing up, or even sexual preferences different from heterosexuals; despite having been raised in a heterosexual family. This stance argues that we don't question procreation and in some cases the adoption of children by heterosexual people with problems such as bipolarity, alcoholism or drug addiction, which could be considered, and that has nothing to do with sexual orientation [14], and can put at risk the development and upbringing of children, whether born naturally, through assisted reproduction technologies or adoption. Given the polarization of the discourse, bioethics faces the need to generate rational public debates on this subject and a balanced discussion between both positions to avoid any form of discrimination towards homosexual parents and adoptive children, and be open to the possibility that more children can be adopted and have better opportunities. National and international homoparental adoption could help more children with no home or family in Mexico [15].

The discussion of homoparental adoption should not focus on prejudices or discriminatory hypotheses but on the best interest of the child and the fundamental rights of all those involved in the adoption process. This prohibition is not only a matter of rights but also, a problem of social perception and acceptance, which, on the one hand, carries within itself the traditional idea of family and on the other (given the progress of individual rights) the problem of discrimination.

\section{Discrimination-Exclusion of Same-Sex Couples}

The LGBTI community has suffered systematically discrimination, not only by society but also by the State particularly in matters of health and other fundamental rights like the freedom of having a family and the possibility of adoption as individual or as couple. Sexual orientation is one of the most frequent factors of discrimination and violence in addition to ethnicity, sex, age and socioeconomic status, not only in Mexico but also in the rest of Latin America [16].

Gilbert Hottois, philosopher bioethicist, affirms that discrimination is to distinguish, differentiate with more or less serious practical consequences and based on unjustifiable criteria, and that the criteria for discrimination are unjustifiable either for logical and objective reasons or for moral reasons [17]. The prohibition of homoparental adoption in Latin America is a form of discrimination based mainly in moral criteria as we explained earlier.

From a sociological perspective, discrimination is understood as a type of social relation in which a certain group of people are stigmatized and devalued, resulting in acts of contempt and abuse that because of their constant and repeated installation become harmful to the lives of the people who conforms it. Taking as a point of departure some particular feature of these groups to denigrate or exclude them in access to certain goods or interests [18] Exclusion is one of the extreme consequences of discrimination.

From a bioethical perspective nothing justifies the discriminatory behavior in the prohibition of homoparental adoption, since it is a form of restriction that impairs the exercise of universal rights and those established in the different constitutions of Latin-American countries and the world. It also ignores what the Universal Declaration on Bioethics and Human Rights of UNESCO states: "No individual or group should be submitted for any reason, in violation of human dignity, human rights and fundamental freedoms, discrimination or stigmatization" [19].

The problem of discrimination in Latin America against the LGBTI community is lower than in some countries of Sub-Saharan Africa due to the rise of the fundamentalist evangelical churches and the Middle East where Islam is practiced and homosexuality is not only pursued, but is penalized by death due to sharia (Islamic law) as in Iran, Mauritania, Nigeria (northern area), Pakistan, Saudi Arabia, Sudan, Yemen and Afghanistan [20]. 
In Mexico, social perception about the union between same-sex couples and homoparental adoption was analyzed in the National Survey on Discrimination in 2010, made by the National Council of Discrimination Prevention, in its results on sexual diversity was found that 7 out of 10 people over 40 disagree with allowing couples of lesbian women to adopt children. 6 out of 10 between 12 and 39 years have the same opinion. The population in Mexico shows more tolerance for adoption by lesbian women than by gay men couples. 8 out of 10 over 50 years say they disagree that gay male couples are allowed to adopt boys and girls. 7 out of 10 between the ages of 30 and 49 say the same thing [21].

Parametría, a firm that carries out strategic research and market analysis in Mexico held in its parametric chart Mexicans Divided on the Rights of the Homosexuals, carried out in 2013, that $70 \%$ of the population disagrees with the adoption of children by same-sex couples and $51 \%$ say that the union between men and women is the only one that must be recognized in society [22]. Mexico, is the second country of the Organization of American States with greater violence towards the LGBTI community after Brazil according to the statistical record of the Inter-American Commission of Human Rights between 2013 and 2014 there were 86 attacks in Mexico; 76 of them, homicides [23]. Honduras has also suffered hate crimes against the LGBTI community, reporting between 2009 and 2012, 186 complaints of deaths; most of these crimes have not been punished [24].

Some Latin American countries suffered in the past laws that criminalized homosexuality, for example Nicaragua, the only country that considered it as a crime until March 2008 when the penal code was revoked, repealing article 204 to make it legal to be homosexual. Likewise, in Cuba, homosexuality was pursued for decades, nowadays it is no longer punished and in recent years has sought to recognize the rights of homosexual people and penalize homophobia [25].

In Chile, the civil union between people of the same sex was approved on October 22, 2015, but this excludes the possibility of homoparental adoption, which is why it is currently sought to approve equal marriage to homosexual couples. At this moment, homoparental adoption is under discussion and legislation. It is important to say that it was until 2004 that civil divorce was legalized in Chile. In the surveys on tolerance and non-discrimination carried out by the Ideas Foundation and the Department of Sociology of the Faculty of Social Sciences of the University of Chile measurements of high homophobia rates were observed, although comparing the 1996 survey to the 2002, it can be noticed a progressive transformation to a greater tolerance towards the LGBTI community. The 2006 World Values Survey also reported high rates of rejection of non- heterosexual people and practices [26].

The exclusion of homosexual couples in the adoption process is mainly associated from a bioethical perspective with the problem of discrimination; it was born from the idea that children may suffer moral and psychological damage when adopted by same-sex couples. Moreover, it is associated with human dignity, which has as its central axis the basic capacity that we all have to elaborate our project of life and self-determination as Lizbeth Sagols affirms in Interfaz bioética, dignity is the very foundation of The Universal Declaration of Human Rights when states that "Every man is born free and worthy", that is, every human being has the right to self-determination, and is not a mean to serve the ends of others, because he was born as an indeterminate being, "open" and free [27]. The violation of the dignity of the LGBTI community not only permeates the legal sphere, but also health. The World Health Organization considered homosexuality as a disease until May 17 of 1990 when it was removed from the International Classification of Diseases [28]. Is urgent the presence of bioethics in the discussion of homoparental adoption and also in health policy-making, so public institutions and society are aware of the risks and prevent the violation of human rights, and overall promote the depathologization of homosexuality.

\section{Social Justice and the Adoption of a Child}

The prohibition of homoparental adoption is not only a problem of human dignity, discrimination and exclusion as stated in the previous section; it is also a problem of social justice. We must consider that children left in the care of the State have the right to be adopted, and the opportunity to be in a family, which can provide decent housing, food (sufficient, nutritious and with quality), access to health, education and an adequate standard of living. They also have the right to be loved and understood, basic aspects that are given during the upbringing of wanted children, regardless of whether their parents are heterosexual or homosexual or if the children are genetic or adopted. Both, rights and emotional issues, are minimums for healthy development of children and guarantee their best interest as set out in the Convention on the Rights of Children in the articles 18, 19, 21, 23, 24, 27 and 28, drawn up by the United Nations, since September of 1990 [29] If the child's well-being is excluded from the discussion, it would only focus on the rights of adults. Social justice is associated with the promotion of well-being and the effort to promote it, based on the physical, psychological and social factors affecting children without a family.

Powers and Faden, philosophers at the Kennedy Institute of Ethics at Georgetown University argue that addressing social justice requires talking about wellness and its dimensions (health, personal safety, reasoning, respect, 
union and self-determination). Each of these dimensions has an independent moral meaning and those with a special moral urgency matter in social justice because they are of central interest to all. These dimensions offer different lenses through which the justice of political structures, social practices and institutions can be evaluated [30].

The prohibition of homoparental adoption reduces opportunities for children, which in itself is low because most people do not want to adopt but rather to conceive of their own, and now is more feasible with the use of reproductive technologies. Same-sex couples may prefer (if they have access to them) a genetic child and not an adopted child. Another aspect that diminishes the possibility of being adopted is the age of the child, in general, couples prefer to adopt children under 5 years or babies, and also they have to face complex and slow procedures to carry out the adoption.

It is essential to have a dialogue between the predominant moral views (liberal and conservative) about the prohibition of homoparental adoption not only in terms of rights but also inequity for children and gay couples. It should also be mentioned that nothing will guarantee that adoptive parents will truly love their adoptive children and that there is a possibility that their desire to adopt is simply the realization of a family ideal.

\section{Bioethics Principles and Homoparental Adoption}

It is urgent to include bioethics in the discussion of homoparental adoption in Latin America. The debate has to move toward a secular and bioethical perspective, free of dogmas and religious influences that far from helping harm the public discussion and their decisions, misinforming the population, creating aversion towards the LGBTI community. We need an open dialogue between the different moral visions; center the discussion in secular principles and values so the dialogue is ethical, and public speech and legislation is not delayed. Secular bioethics seeks unity in plurality on the basis of universal human rights. Secular bioethics is inclusive. Likewise, diversity, multiculturalism and democracy are essential elements of contemporary societies. Inclusion of minorities, non-discrimination and social justice must be ensured by the State. Everyone has the right to join in civil marriage, have a family and if the individual wishes, adopt without distinguishing whether or not is in civil union or if is heterosexual.

The marriage of same-sex couples and homoparental adoption, remain very controversial in Latin America due to the strong influence of the conservative stance on social thinking. One of the most important tasks of secular bioethics is to generate an open and tolerant dialogue between the different. We need an informed public debate, and the active participation of legislators and citizens in the resolution of these controversies.

The prohibition of homoparental adoption generates a message of social intolerance. We need a tolerant attitude which involves the recognition and respect of the differences inherent in human nature, diversity in all its aspects, in the sexual, cultural, religious, political and social. Voltaire maintains that tolerance has never caused a civil war, unlike intolerance that has covered the land with massacres [31]

Western bioethics is based on four basic ethical principles broadly developed by James Childress and Tom Beauchamp. The adoption of parentless children is directly related with one of these principles: non-maleficence (called the principle of principles) because it ensures no harm; children from the time they are abandoned by their biological parents are affected in emotional, physical, social, educational and economic health. One of the rules of non-maleficence is not to deprive others of the goods of life [32]. Children, in addition to abandonment, suffer deep deficiencies, sometimes mistreatment and discrimination within charitable or governmental institutions that will take care of them until they are of legal age if they are not adopted. When leaving these institutions they may have shortcomings in the development of psychosocial and educational capacities, this could limit them to fend for them-selves and face the world.

Is not sufficient to appeal to the principle of nonmaleficence in the discussion of homoparental adoption, we will also include the principles of dignity, integrity and vulnerability proposed by Peter K, et al. in La mundialización de la ética. These principles offer a way of reasoning by which we can expect to overcome some of the dilemmas, crises and challenges we face today. Kemp proposes dignity as a universal principle of understanding the value of the human being and maintains that to this principle we must embody the one of integrity. Integrity means literally that we must not touch, damage, alter, but we must respect and protect, and this can be achieved by incorporating the child into an environment where there is a desire to ensure his or her well-being and provide the means for them to thrive. Integrity, adds something to dignity, because it also refers to what constitutes a totality, coherence. The principle of vulnerability is one of the most important in the debate about homoparental adoption because it expresses care by considering the fragility of an intact wholeness that can be ruined. In this sense, not only the children to adopt are vulnerable, but also those who want to adopt. Kemp also recognizes social vulnerability, which pertains to the fragility of human capacities to construct the human being 
as a coherent narrative and to distribute messages, goods and services. It also affirms that interventions can lead to isolation and fear, and the vulnerable being has the need to be helped and protected [33].

To end this analysis, I would like to include the right to privacy. This right is of special importance because it is part of the fundamental rights that refer to the personality and allows the development of a full life as the right to honor and dignity. In our lives there is an untouchable private space, the realm of intimacy, an area over which no external interference is possible; because it is information that does not affect or impact society or the rights of others, because it refers to strictly personal or family matters, or because the use or knowledge of that information does not benefit or is not useful to society, and it can be the origin or cause of discriminatory actions against the individual, which would be in an absolute state of defenselessness [34]. When trying to adopt, same-sex couples or individuals could appeal to the right of privacy without being enforced to disclose intimate information like the biological sex they had when they were born, their sexual orientation, or the submission of a civil marriage contract in order to carry it out the adoption. Information of an intimate nature should be protected by the State, especially in Latin-American countries, because violence and discrimination against the LGBTI community is frequently experienced by them.

\section{Conclusion}

Latin America needs to open the discussion on homoparental adoption and include the secular bioethical perspective, free of religious dogmas; a perspective that seeks unity in plurality. Homoparental adoption can be seen not only from a standpoint that contemplates the rights of adults but also considers the problem of social justice towards children without a family. The debate on the problem of exclusion-discrimination is a bioethical obligation. The institution of adoption in most countries in Latin America violates fundamental rights and it does not ensure the free and peaceful exercise of them. It is necessary to legislate in favor of children so they can be adopted by people who want them, regardless of whether or not they are legally married, are heterosexual or single, giving children the opportunity to develop their capacities and integration into society. We also need to promote education and awareness in society to prevent violence and discrimination against the LGBTI community. Another important task is to teach bioethics at all levels of education and promote ethical minimums like tolerance, respect and listening. Latin America needs an open dialogue that is peaceful an inclusive of all the perspectives. Starting with a secular dialogue which can appeal to tolerance, the right to privacy, and the fundamental bioethical principles.

\section{References}

1. (2016) The state of the world's children 2016: A fair chance for every child. United Nations Children's Fund (UNICEF). New York, pp: 133.

2. (1948) Universal Declaration of Human Rights. United Nations.

3. (2017) Approval of the Equal Marriage Law, Law No. 19075. Normativas y Avisos Legales del Uruguay 1: 774.

4. (2017) Modifications to the Equal Marriage Law, Law $\mathrm{N}^{\circ}$ 19119. Normativas y Avisos Legales del Uruguay 1: 361.

5. (2012) Mexico is the second most Catholic country in the world after Brazil, with 92.9 million followers, around $82.7 \%$ of the total population. National Institute of Statistics and Geography.

6. It is stated that the protection of the best interest of children enshrined in Article 4 of the Political Constitution of Mexico, is a principle that requires compliance by the State in all levels of government and areas of responsibility and although it is true that in the case of the civil institution of adoption, the rights of minors subject to adoption are in a prevailing position against the interest of the adopter or adopters, it is also true that this does not mean that the sexual orientation of a person or a couple degrades them to be considered, for that alone, as harmful to the development of a minor and, therefore, not allow him or her to adopt. Any argument in that direction would imply using a reasoning prohibited by Article 1 . Which specifically prohibits the discrimination of persons by reason of their preferences, which would also be contrary to the interpretation that the Supreme Court of Justice has developed with respect to the type of family protected by Article 4 of the constitution and the rights of minors? Thus, in the case of adoption, what is required by the principle of the best interest of the child is that the applicable legislation allows to delimit the universe of possible adopters, on the basis that they offer the necessary conditions for the care and development of the child established In the law, so that the enforcement authority evaluates and decides with respect to which it represents its better option of life, since to maintain that the homoparental families do not satisfy this scheme would imply to use a reasoning constitutionally contrary to the interests of the children that, due to the right to a family, must be protected. Novena Época Registro: 161284 Instancia: Pleno Jurisprudencia Fuente: Semanario Judicial de la Federación y su Gaceta Tomo XXXIV, Agosto de 2011 Materia(s): Constitucional Tesis: P. /J. 13/2011: 872. 
7. (2010) Same-sex marriage. Modification to the civil code, Law 26,618. Buenos Aires, Argentina

8. (1997) Adoption, Law 24,779. Buenos Aires, Argentina.

9. Perasso V (2010) Argentina: Demonstration against homosexual marriage law. BBC Mundo.

10. (2011) Supremo recognizes same-sex union. Supreme Federal Court.

11. (2015) Manda De Inconstitucionalidad En Materia De Adopcion Por Parejas Del Mismo Sexo. Sentencia C-683/15

12. Ratzinger J (2003) Considerations about the projects of legal recognition of the unions between homosexual people. Vatican: Congregation for the Doctrine of the Faith.

13. Kass L, Mansfield H (2013) Brief of Leon Kass. Harvey Mansfield and the Institute of Marriage and Public Policy as Amici Curiae in support of petitioners. United States: Supreme Court of United States; American Bar Association, pp: 11-17.

14. Harris J, Holm S (2004) The future of human reproduction: Choice and regulation. New York: Oxford Press, pp: 5-37.

15. (2013) The National System for the Integral Development of the Family in Mexico there were 25,700 children and adolescents in 922 shelters; 805 private and 117 public that are institutionalized by abandonment or mistreatment by their parents.

16. (2016) Aglobal report of Trans Murder Monitoring Project indicates that in Latin America some studies have begun to evidence homophobic and transphobic violence in the education sector; the prevalence of general bullying can be between $40 \%$ and $70 \%$. Violence in the school setting increases the risk of depression, substance abuse, and suicide. In Latin America, between $44 \%$ and $70 \%$ of Trans women have felt the need to leave home or were forced to leave their homes. Lesbian women are vulnerable to physical and emotional violence in their communities. Intersex people are subjected to sex reassignment surgeries without their consent and most of these procedures cause irreversible damage. Pan American Health Organization.

17. Hottois G (2007) Diversity without discrimination: between modernity and postmodernity. Colombian Journal of Bioethics 2(2): 45-76.

18. Gutiérrez G (2014) Without rights, exclusion and discrimination in today's Mexico. In: The category of discrimination and its relationship with the Human Rights paradigm: A critical point. Mexico: UNAM 3: 6-7.
19. (2005) Article 11 of the Universal Declaration on Bioethics and Human Rights of UNESCO. New York: UNESCO.

20. Pérez J, Sánchez V, Wilhelmi M, Bondia D, Borge R, et al. (2008) Human rights in the XXI century: continuity and changes. Spain: Editorial Huygens, pp: 374.

21. (2010) National Survey on Discrimination in Mexico.

22. (2013) Parametric Chart: Mexicans divided by homosexual rights. Mexico: National Survey on Housing.

23. (2015) Violence against Lesbian, Gay, Bisexual, Trans and Intersex Persons in the Americas: Inter-American Commission on Human Rights. Violence against LGBTI Persons, pp: 1-284.

24. Ibid.

25. Tin L (2003) Homophobia Dictionary. France: University Press, pp: 58.

26. (2012) Composite index of stigma and discrimination against homosexual men, other MSM and transgender women in Chile. Study synthesis. Ministry of Health Dechile, pp: 15.

27. Sagols L (2006) Bioethics interfaces. Mexico: Fontamara. UNAM, pp: 49.

28. (1990) International Classification of Diseases. World Health Orignization.

29. Conventions developed by the UN are mandatory in their member states.

30. Powers M, Faden R (2006) Social justice the moral foundations of public health and health policy. United Kingdom: Oxford University Press, pp: 15.

31. (1763) Treatise on tolerance. Mexico: Public Editorial, pp: 8.

32. Childress J, Beauchamp T (1999) Principles of Biomedical Ethics. Madrid: Masson: 183.

33. Kemp P (2007) The Globalization of Ethics. Mexico: Fontamara, pp: 52-59.

34. Celis M (2006) The Protection of Privacy as a fundamental right of Mexicans. In: Studies in Tribute to Marcia Muñoz de Alba Medrano. Protection of the person and Fundamental Rights. Mexico: UNAM, IIJ: 74. 